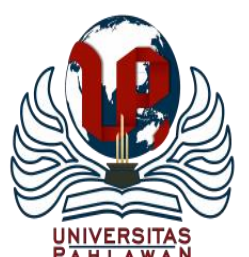

Jurnal Basicedu Volume 5 Nomor 1 Tahun 2021 Halaman 446-452

JURNAL BASICEDU

Research \& Learning in Elementary Education

https://jbasic.org/index.php/basicedu

\title{
Penggunaan Media Big Book untuk Menumbuhkan Minat Baca Siswa di Sekolah Dasar
}

\author{
Anggy Giri Prawiyogi', Tia Latifatu Sadiah², Andri Purwanugraha ${ }^{3}$, Popy Nur Elisa \\ Universitas Buana Perjuangan, Indonesia ${ }^{1,2,4}$ \\ STKIP Subang, Indonesia ${ }^{3}$ \\ E-mail: anggy.prawiyogi@ ubpkarawang.ac.id tia.latifatu@ubpkarawang.ac.id², \\ andripurwanugraha22@gmail.com ${ }^{3}$ popyelisa@mhs.ubpkarawang.ac.id ${ }^{4}$
}

\begin{abstract}
Abstrak
Penelitian ini dilatarbelakangi oleh rendahnya minat siswa terutama pada minat membaca. Media pembelajarannya menggunakan media big book. Penelitian ini bertujuan untuk mengetahui penggunaan media big book terhadap minat membaca siswa sekolah dasar kelas II SDIT Cendekia, karena saat melakukan observasi di sekolah tersebut tidak semua siswanya mempunyai minat membaca yang tinggi dan kurangnya media pembelajaran yang menarik. Penelitian ini merupakan jenis penelitian kualitatif deskriptif. Subjek penelitian adalah seluruh siswa kelas II SDIT Cendekia yang berjumlah 26 siswa terdiri dari 15 siswa perempuan dan 12 siswa laki-laki. Metode pengumpulan data yang digunakan adalah observasi, kuesioner/angket, wawancara, dan dokumentasi. Penelitian menunjukan bahwa penggunaan media big book dikatakan berhasil diterapkan di kelas rendah untuk menumbuhkan minat membaca. Dari hasil penilitian yang telah dilakukan dapat disimpulkan bahwa penggunaan media big book dapat menumbuhkan minat membaca siswa di sekolah dasar kelas II SDIT Cendekia Purwakarta
\end{abstract}

Kata kunci : Media Big Book, Minat Baca

\section{Abstract}

This research is motivated by the low interest of students, especially in reading interest. The learning media uses the big book media. This study aims to determine the use of big book media on the reading interest of grade II elementary school students at SDIT Cendekia, because when making observations at the school not all students have a high reading interest and the lack of interesting learning media. This research is a descriptive qualitative research. The research subjects were all students of class II SDIT Cendekia, totaling 26 students consisting of 15 female students and 12 male students. The data collection methods used were observation, questionnaires / questionnaires, interviews, and documentation. Research shows that the use of big book media is said to be successfully applied in lower classes to foster interest in reading. From the results of the research that has been done, it can be concluded that the use of big book media can foster student interest in reading in grade II elementary schools of SDIT Cendekia Purwakarta.

Keywords: Big book media, interest in reading

Copyright (c) 2021 Anggy Giri Prawiyogi, Tia Latifatu Sadiah, Andri Purwanugraha, Popy Nur Elisa $\triangle$ Corresponding author

Address :-

Email : anggy.prawiyogi@ubpkarawang.ac.id

ISSN 2580-3735 (Media Cetak)

Phone :-

ISSN 2580-1147 (Media Online)

DOI: https://doi.org/10.31004/basicedu.v5i1.787 
447 Penggunaan Media Big Book untuk Menumbuhkan Minat Baca di Sekolah Dasar - Anggy Giri Prawiyogi, Tia Latifatu Sadiah, Andri Purwanugraha, Popy Nur Elisa

DOI: https://doi.org/10.31004/basicedu.v5i1.787

\section{PENDAHULUAN}

Kegiatan membaca memerlukan minat bagi setiap individu karena minat membaca perlu ditanamkan dan ditumbuhkan sejak anak masih kecil sebab minat membaca pada anak tidak akan terbentuk dengan sendirinya, tetapi sangat dipengaruhi oleh stimulasi yang diperoleh dari lingkungan anak. Keluarga merupakan lingkungan paling utama dan dominan dalam menanamkan, menumbuhkan dan membina minat membaca anak di lingkungan rumah. Orang tua perlu menanamkan kesadaran terhadap pentingnya membaca dalam kehidupan anak, setelah itu baru guru di sekolah, teman sebaya dan masyarakat.

Sedangkan menurut pendapat Dalman (2013:144) berpendapat bahwa minat membaca merupakan aktivitas yang dilakukan dengan penuh ketekunan dalam rangka membangun pola komunikasi dengan diri sendiri untuk menemukan makna tulisan dan menemukan informasi untuk mengembangkan intelektualitas yang dilakukan dengan penuh kesadaran dan perasaan senang yang timbul dari dalam dirinya.

Ada beberapa aspek dalam minat baca anak menurut Safari (2003:321) aspek minat baca adalah sebagai berikut :

\section{a. Perasaan Senang}

Seorang siswa yang memiliki perasaan senang atau suka terhadap suatu mata pelajaran, maka siswa tersebut akan terus mempelajari ilmu yang disenanginya. Tidak ada perasaan terpaksa terhadap siswa dalam mempelajari bidang tersebut.

\section{b. Ketertarikan Siswa}

Berhubungan dengan daya gerak yang mendorong untuk cenderung merasa tertarik pada orang, benda, kegiatan atau bisa berupa pengalaman afektif yang dirangsang oleh kegiatan itu sendiri.

\section{c. Perhatian Siswa}

Perhatian merupakan konsentrasi atau aktivitas jiwa terhadap pengamatan dan pengertian, dengan mengesampingkan yang lain dari pada itu. Siswa yang memiliki minat terhadap objek tertentu, dengan sendirinya akan memperhatikan setiap objek tersebut.

\section{d. Keterlibatan Siswa}

Ketertarikan seseorang akan suatu objek yang mengakibatkan orang tersebut senang dan tertarik untuk melakukan atau mengerjakan kegiatan dari objek tersebut.

Melihat kenyataan di lapangan bahwa tidak semua siswa gemar membaca, menjadikan suatu tantangan bagi kita untuk menjadikan kegiatan membaca menjadi sebuah kegiatan yang menarik dan rutin dalam agendanya sehari-hari. Membaca akan menjadi menarik apabila orang memahami hakikat membaca, manfaatnya serta menggunakan media yang tepat dalam pengajaran membaca.

Setiap proses kegiatan pembelajaran dengan menggunakan media akan lebih menarik terhadap peserta didik. Menurut pendapat Sadiman (2014:7) media merupakan segala sesuatu yang dapat digunakan untuk menyalurkan pesan dari pengirim ke penerima sehingga dapat merangsang pikiran, perasaan, perhatian, minat serta perhatian anak sehingga proses belajar terjadi dengan baik.

Media big book berpengaruh terhadap minat membaca siswa, karena media big book merupakan buku cerita yang berukuran besar yang di dalamnya terdapat cerita sederhana dan gambar yang berwarna. Media big book tentu menarik bagi siswa kelas rendah karena siswa akan senang membaca buku cerita yang banyak gambar, berwarna, dan tulisan yang besar. Big Book membuat siswa paham dan mengerti yang disampaikan terhadap gambar ilustrasi, dengan media Big Book berpengaruh 
448 Penggunaan Media Big Book untuk Menumbuhkan Minat Baca di Sekolah Dasar - Anggy Giri Prawiyogi, Tia Latifatu Sadiah, Andri Purwanugraha, Popy Nur Elisa

DOI: https://doi.org/10.31004/basicedu.v5i1.787

terhadap meningkatkan minat membaca siswa. Hal tersebut dapat meyakinkan bahawa pembelajaran dengan menggunakan media big book menarik perhatian siswa di dalam kelas dan dapat menumbuhkan minat siswa dalam membaca.

Menurut pendapat Solehuddin (2008:7) menyatakan bahwa big book adalah buku bergambar yang dipilih untuk dibesarkan dan memiliki kualitas khusus. Kualitas khusus disini maksudnya adalah big book dapat melibatkan ketertarikan anak dengan cepat karena gambar yang dimilikinya, mengandung irama yang menarik bagi anak, memiliki gambar yang besar, ada tulisan yang diulangulang, memuat kosakata yang direncanakan dan sebagian diulang-ulang, mempunyai alur cerita yang sederhana.

Menurut Septiyani, dkk (2017:51) Langkah-langkah yang dilakukan guru dan siswa dalam menggunakan media big book: (1) Guru mengatur tempat duduk siswa supaya lebih nyaman, (2) Guru duduk di depan sambil memegang media dan membawa penggaris untuk menunjuk gambar, (3) Guru menunjukkan gambar dan melakukan tanya jawab dengan siswa terkait judul gambar, (4) Guru menunjukkan setiap gambar pada siswa dan siswa menceritakan gambar yang ditunjuk oleh guru, (5) Guru mempertegas cerita yang ada pada media big book, (6) Setelah cerita selesai siswa diminta menceritakan kembali secara bergantian di depan kelas.

Menurut pendapat Karges Bone (USAID, 2014: 43) menyatakan bahwa big book memiliki ciri-ciri sebagai berikut: 1) Cerita singkat; 2) Pola pengulangan kata; 3) Pola kalimat jelas; 4) Gambar memiliki makna; 4) Jenis dan ukuran huruf jelas terbaca; 6) Jalan cerita mudah dipahami.

\section{METODE}

Penelitian ini menggunakan pendekatan kualitatif deskriptif karena bertujuan mendeskripsikan fenomena, peristiwa dan sikap suatu kelompok. Menurut Afrizal (2015:173) kualitatif merupakan sebuah prosedur ilmiah untuk menghasilkan pengetahuan tentang realitas sosial dan dilakukan dengan sadar dan menggunakan pendekatan kualitatif sebagai langkah melakukan penelitian yang diharapkan menemukan realitas sosial yakni minat membaca siswa sekolah dasar.

Metode penelitian yang digunakan dalam penelitian ini adalah metode deskiptif yang bertujuan untuk menggambarkan dan menjelaskan keadaan minat membaca siswa sekolah dasar. Menurut sukmadinata (2010:72) deskriptif adalah penelitian paling dasar yang ditujukan untuk mendeskripsikan atau menggambarkan fenomena-fenomena yang ada baik fenomena yang bersifat alamiah atau rekaan manusia. Aktivitas ini mengkaji bentuk, aktivitas, karakteristik perubahan, hubungan, kesamaan, dan perbedaan dalam fenomena lain.

Subjek penelitian ini adalah siswa kelas 2 SDIT Cendekia dengan jumlah 26 siswa yang terdiri dari 11 perempuan 15 lakilaki. Peneliti menemukan masalah pada saat melakukan penelitian yaitu minat membaca siswa masih rendah dan kurangnya media pembelajaran.

Instrumen yang digunakan dalam penelitian penggunaan media big book terhadap minat membaca siswa kelas 2 ini dengan kuesioner/angket dan hasil wawancara. Responden yang diambil untuk penelitian yaitu 2 siswa didampingi orang tua, 1 Guru kelas, dan 1 Kepala Sekolah.

Teknik pengumpulan data menggunakan empat metode yaitu observasi 
449 Penggunaan Media Big Book untuk Menumbuhkan Minat Baca di Sekolah Dasar - Anggy Giri Prawiyogi, Tia Latifatu Sadiah, Andri Purwanugraha, Popy Nur Elisa

DOI: https://doi.org/10.31004/basicedu.v5i1.787

dengan melihat dan mengamati keadaan yang sebenarnya, metode kuesioner/angket yang berbentuk pernyataan untuk mengetahui sejauh mana minat membaca siswa dengan menggunakan media big book, wawancara untuk memperoleh informasi tentang proses pembelajaran dengan menggunakan media big book terhap minat membaca siswa kelas $2 \mathrm{di}$ SDIT Cendekia dan dokumentasi berupa tulisan, foto ketika peristiwa pelaksanaan penelitian. Selanjutnya untuk memperoleh kredibilitas data pada penelitian ini adalah tringulasi metode yaitu membandingkan data yang diperoleh dengan menggunakan metode observasi, kuesioner/angket, wawancara dan dokumentasi terhadap subjek peneliti.

\section{Observasi}

Observasi atau yang disebut juga dengan pengamatan meliputi kegiatan pemuatan perhatian terhadap sesuatu objek dengan menggunakan seluruh indra jadi, observasi merupakan metode pengumpulan data yang menggunakan panca indra disertai dengan pencatatan secara perinci terhadap obyek penelitian.

\section{Kuesioner/Angket}

Kuesioner/angket merupakan metode pengumpulan data yang telah dilakukan dengan cara memberikan beberapa macam pertanyaan yang berhubungan dengan masalah penelitian. Menurut Sugiyono (2017:142) kuesioner merupakan metode pengumpulan data yang dilakukan dengan cara memberi seperangkat pertanyaan atau pernyataan tertulis kepada responden untuk dijawabnya.

Tabel 3.1 Kriteria Penilaian Kuesioner/Angket

\begin{tabular}{|l|l|l|}
\hline Alternatif Jawaban & $\begin{array}{l}\text { Skor } \\
\text { Positif }\end{array}$ & $\begin{array}{l}\text { Skor } \\
\text { Negatif }\end{array}$ \\
\hline Sangat Sesuai (SS) & 4 & 1 \\
\hline
\end{tabular}

\begin{tabular}{|l|l|l|}
\hline Sesuai (S) & 3 & 2 \\
\hline Tidak Sesuai (TS) & 2 & 3 \\
\hline $\begin{array}{l}\text { Sangata Tidak Sesuai } \\
\text { (STS) }\end{array}$ & 1 & 4 \\
\hline
\end{tabular}

(Sugiyono, 2009:135)

\section{Wawancara}

Menurut pendapat dari Sugiyono (2017:231) wawancara merupakan pertemuan dua orang untuk bertukar informasi dan ide melalui tanya jawab, sehingga dapat dikonstuksikan makna dalam suatu topik tertentu. Wawanacara digunakan sebagai teknik pengumpulan data apabila peneliti ingin melakukan studi pendahuluan untuk menentukan permasalahan yang harus diteliti, tetapi juga apabila peneliti ingin mengetahui hal-hal responden yang lebih mendalam.

\section{Dokumentasi}

Dokumentasi merupakan pengamatan secara langsung untuk mendapatkan data yang diperoleh peneliti sesuai dengan pembahasan. Hal ini dilakukan untuk mengetahu gambaran nyata dilapangan dan mendapatkan sumber primer tentang hubungan budaya organisasi sekolah terhadap motivasi kerja guru. Menurut Sugiyono (2017:240) mengatakan bahwa studi dokumentasi merupakan pelengkap dari penggunaan metode observasi dan wawancara dalam penelitian kualitatif.

Dalam suatu penelitian kualitatif ini, proses analisis data dilakukan dari awal hingga akhir. Hal ini yang menjadi perbedaan anatara penelitin kualitatif dengan kuantitatif, dimana pada penelitian kuantitatif proses analisis data tersebut dilakukan setelah data penelitian itu terkumpul di akhir penelitian, lain halnya dengan penelitian kualitatif bahwa terkumpulnya data dari awal hingga akhir penelitian dan tidak memiliki batasan waktu penelitian. Analisis data penelitian menurut Seiddel (Moleong 2002:248) prosesnya 
450 Penggunaan Media Big Book untuk Menumbuhkan Minat Baca di Sekolah Dasar - Anggy Giri Prawiyogi, Tia Latifatu Sadiah, Andri Purwanugraha, Popy Nur Elisa

DOI: https://doi.org/10.31004/basicedu.v5i1.787

berjalan sebagai berikut : (1) mencatat yang menghasilkan catatan lapangan, dengan hal itu diberikan kode agar sumber datanya tetep dapat ditelusuri (2) mengumpulkan, memilahmilah, mengklarifikasikan, menyintesiskan, membuat ikhtisar, dan membuat indeksnya (3) berpikir, dengan jalan membuat agar kategori data itu mempunyai makna mencari dan menemukan pola dan hubungan-hungan, dan membuat temuan-temuan umum. Dalam penelitian kualitatif, proses analisis data itu dilakukan dengan tahapan menurut Miles \& Huberman (Kurniawan 2018:241).

\section{HASIL PENELITIAN DAN PEMBAHASAN}

Proses kegiatan pembelajaran dengan menggunakan media akan lebih menarik terhadap siswa. Karena media merupakan segala sesuatu yang dapat digunakan untuk menyalurkan pesan dari pengirim ke penerima sehingga dapat merangsang pikiran, perasaan, perhatian, minat serta perhatian anak sehingga proses belajar terjadi dengan baik. Media big book merupakan buku besar yang berkarakteristik memiliki gambar, warnawarna, dan tulisannya berukuran besar dapat di baca berulang-ulang, karena media big book memiliki cerita yang sederhana dan media big book juga cocok untuk siswa kelas rendah.

Media big book sangat baik dipergunakan di kelas awal karena dapat membantu meningkatkan minat siswa dalam membaca. Kegiatan membaca memerlukan minat bagi setiap individu karena minat membaca perlu ditanamkan dan ditumbuhkan sejak anak masih kecil sebab minat membaca pada anak tidak akan terbentuk dengan sendirinya, tetapi sangat dipengaruhi oleh stimulasi yang diperoleh dari lingkungan anak.

Untuk mencapai tujuan yang sesuai dengan proses minat membaca siswa, orang tua juga mempunyai peran untuk memberikan contoh kepada anaknya di rumah, dengan menyediakan waktu dan perhatian kepada anaknya. Minat membaca pertama kali harus ditanamkan melalui pendidikan dan kebiasaan keluarga di rumah. Salah satu contohnya orang tua membacakan buku cerita kepada anaknya sehingga anak tertarik untuk membaca buku maka anak dapat terbiasa dalam membaca.

Peran guru terhadap minat membaca juga sangat penting karena guru harus memberikan susana proses pembelajaran yang menyenangkan sehingga pembelajaran akan berjalan dengan baik. Guru yang kreatif akan menciptakan suasana proses belajar dan mengajar yang menarik yaitu dengan media pembelajaran.

Hasil dari penggunaan media big book di kelas II SDIT Cendekia, siswa lebih antusias/semangat terhadap proses pembelajaran. Karena dengan adanya media big book siswa lebih tertarik sehingga minat siswa dalam membaca lebih tinggi. Media big book berhasil diterapkan di kelas rendah seperti di kelas II karena media big book merupakan buku besar yang di dalamnya memiliki cerita sederhana, mempunyai banyak gambar yang berwarna dan memiliki huruf yang besar.

Media big book sangat berpengaruh bagi siswa kelas II karena media big book mempunyai kata yang dapat diulang-ulang sehingga siswa yang mempunyai keterlambatan dalam membaca akan lebih cepat memahami. Belajar menggunakan media big book akan lebih antusias dalam proses pembelajaran dibandingkan belajar tidak menggunakan media, proses pembelajaran yang tidak menggunakan media siswa terlihat tidak bersemangat karena bosan dengan dalam cara pembelajarannya yang tidak menarik sehingga minat membaca siswa akan kurang dibandingkan belajar menggunakan media minat siswa dalam membaca akan lebih tinggi. Karena sudah jelas saat penelitian siswa lebih 
451 Penggunaan Media Big Book untuk Menumbuhkan Minat Baca di Sekolah Dasar - Anggy Giri Prawiyogi, Tia Latifatu Sadiah, Andri Purwanugraha, Popy Nur Elisa

DOI: https://doi.org/10.31004/basicedu.v5i1.787

menyukai belajar menggunakan media yaitu media big book.

Hasil wawancara dari R1-R4 terdapat persamaan yaitu sama-sama mengatakan bahwa proses pembelajaran dengan media big book berhasil digunakan sehingga dapat menumbuhkan minat membaca siswa, karena siswa lebih menyukai belajar dengan menggunakan media big book. Media big book merupakan buku besar yang mempunyai cerita sederhana, memiliki gambar yang berwarna, huruf yang besar, dan bisa dapat diulang-ulang sehingga siswa yang mempunyai keterlambatan dalam membaca dapat cepat memahami bacaan tersebut.

\section{KESIMPULAN}

Berdasarkan dari hasil penelitian dan hasil pembahasan maka diperoleh kesimpulan terkait dengan penggunaan media big book terhadap minat membaca siswa sekolah dasar kelas II SDIT Cendekia. Penggunaan media big book tehadap minat membaca telah dilakukan oleh peneliti dengan adanya proses observasi, wawancara, kuesioner/angket, dan dokumentasi untuk mengetahui hasil dari penggunaan media big book tersebut.

Pembelajaran mengunakan media big book dikatakan berhasil diterapkan di kelas II untuk menumbuhkan minat membaca, dengan menggunakan media big book siswa menjadi lebih aktif dan lebih antusias dalam kegiatan membaca. Oleh karena itu guru harus kreatif dalam membuat media pembelajaran sehingga dapat menciptakan suasana belajar yang menarik, agar siswa lebih bersemangat dalam kegiatan proses pembelajaran. Media big book juga dapat membatu siswa yang mempunyai keterlamabatan membaca karena media big book mempunyai kata yang dapat diulangulang dan mempunyai gambar yang menarik sehingga siswa yang terlambat dalam membaca dapat lebih cepat memahami bacaan tersebut.

Berdasarkan hasil kesimpulan dari penelitian ini, maka saran yang dapat diberikan adalah sebagai berikut: Guru harus mengembangkan upaya yang dapat menumbuhkan minat membaca bagi siswa, dengan cara membuat media yang semenarik mungkin dalam setiap proses kegitan belajar. Sehingga dapat menumbuhkan kualitas pembelajaran dengan lebih maksimal dalam menggunakan media pembelajaran, dan membuat siswa lebih aktif. Karena siswa lebih tertarik membaca buku yang banyak gambarnya seperti media big book. Diharapkan bagi peneliti lain untuk menggunakan media pembelajaran yang lebih baik dan lebih menarik lagi agar minat membaca siswa dapat lebih meningkat.

\section{DAFTAR PUSTAKA}

Afrizal. (2015). Metode Penelitian Kualitatif: Sebuah Upaya Mendukung Penggunaan Penelitian Kualitatif dalam Berbagai

Ilmu. Jakarta: PT Raja Grafindo

Persada.

Asep Kurniawan, (2018) Metodelogi Penelitian Pendidikan. Bandung: PT. Remaja Rosdakarya.

Dalman. (2013). Keterampilan Membaca. Jakarta: Raja Grafindo Persada. Jurnal Pendidikan Guru Sekolah Dasar Edisi 6 Tahun ke-6 2017.

Moleong, Lexy. (2012). Metodologi Penelitian Kualitatif. Bandung: PT. Remaja Rosdakarya.

Nana Syaodih Sukmadinata. (2010). Metode Penelitian Pendidikan. Bandung: PT Remaja Rosdakarya. 
452 Penggunaan Media Big Book untuk Menumbuhkan Minat Baca di Sekolah Dasar - Anggy Giri Prawiyogi, Tia Latifatu Sadiah, Andri Purwanugraha, Popy Nur Elisa

DOI: https://doi.org/10.31004/basicedu.v5i1.787

Sadiman, dkk.(2014). Media Pendidikan.

Jakarta: Rajawali Pers Jurnal

Potensia , PG - PAUD FKIP UNIB,

Vol . 2 No . 1 . 2017.

Safari. (2003). Indikator Minat Belajar.

Jakarta: Rineka Cipta. Jurnal Review

Pendidikan Dasar: Jurnal Kajian

Pendidikan dan Hasil Penelitian Vol 3, No 1, Januari 2017.

Septiyani, dkk. (2017) Jurnal Potensia, PG -

PAUD FKIP UNIB, Vol.2 No . 1

. 2017.

Solehuddin, dkk. (2008). Pembaharuan

Pendidikan TK. Jakarta:

Universitas Terbuka Jurnal Potensia,

PG - PAUD FKIP UNIB, Vol . 2

No . 1.2017.

Sugiyono. (2017). Metode Penelitian

Kuantitatif, kualitatif, dan $R \& D$.

Bandung: Alfabeta, CV.

USAID. (2014). Buku Sumber untuk

Dosen LPTK: Pembelajaran Literasi

Kelas Awal di LPTK.

Jakarta:USAID. Jurnal Potensia, PG -

PAUD FKIP UNIB, Vol . 2 No . 1 .

2017 